\title{
Design and Simulate the Solar-Wind-Diesel Stand-Alone Systems for an Institutional Area
}

\author{
Rajiv Ranjan Kumar \\ Research Scholar, \\ Jaipur National University, Jaipur, \\ India
}

\author{
Abhishek Kumar Gupta \\ Assistant Professor, \\ Jaipur National University, Jaipur, \\ India
}

\author{
Ashish Ranjan Kumar \\ Associate Professor, \\ Arya Institute of Engineering \\ \&Technology, Jaipur, India
}

\begin{abstract}
Hybrid energy source is becoming general because it is composed from two or more energy sources. This combination of two or more energy sources is a competent way of generating energy. The amount of the conventional energy sources is reducing day by day. To avoid energy inaccessibility, the use of renewable energy sources is extremely essential. Hybrid operation raises the reliability of stand-alone system, reduces the production cost and guarantees the availability of power. A new technological energy solution delivered by solar-wind and diesel standalone system is facing a high growth rate in recent days. In this paper we are designing the solar-wind \& diesel generator for an Institutional area for providing green energy generation as much as possible. The hybrid system consist solar, wind, diesel generator and batteries with converter. Hybrid Optimization Model for Electric Renewable (HOMER) software is used to design the proposed hybrid renewable energy power system model. The sensitivity analysis was supported out using Homer program. The results are presented to verify the system performance and it has been found that renewable energy sources will replace the conventional energy sources.
\end{abstract}

\section{Keywords}

Renewable energy systems, photovoltaic, wind turbine, diesel generator.

\section{INTRODUCTION}

The Stand-alone micro grids are energy supply systems that are not connected to the main electricity grid. Stand-alone systems are most common as electrification of areas that are not in proximity to the main grid and where grid extension is too expensive. The most common way of ensuring electrification to such areas has been through installation of diesel generators, although micro grids provide good opportunities to consume locally available energy resources. As renewable energy technologies, mainly Photovoltaic (PV) power, have developed regarding price, efficiency and reliability, these are becoming increasingly popular and affordable for rural areas. At the same time, diesel generators suffer from increasing fuel prices, with the additional costs of transportation to remote locations, and low efficiency at low loads. However, its output can be controlled as disparate to solar power, an intermittent resource which varies both on a daily and seasonal basis. Combining a PV system with a generator in a hybrid micro grid makes it possible to limit some of the disadvantages in both technologies. Depending on the requirements of the energy supply, a micro grid might take in an Energy Storage System (ESS) [1].

The stand-alone hybrid solar-wind power generation system is accepted as a viable alternative to grid supply or to conventional fossil fuel based far-off area power supplies all over the world. There are almost 292 off-grid Canadian isolated communities with a total population of almost 194,281 peopling (2006 Statistics Canada Census); they have significant wind energy potentials [2]. The annual demand is almost 31,477,415 MWh /yr. where fossil fuel generation type is generally diesel. As the operation of diesel generators are highly expensive and contribute in carbon emission a different solution is required to minimize the diesel consumption. In the period of 2008-2011 the annual evolution rate of solar photovoltaic power was $147.3 \%$ in Canada. At the same time wind power generation has gained popularity and is estimated to produce $12 \%$ of the world's electricity by 2020 . Consequently, the idea of hybrid operation is gaining attention among the researchers in electrical power industry.

In this paper, a stand-alone hybrid alternative energy system is proposed for Institutional area in Jaipur, Rajasthan. The currently system works there has a continual use of Kirloskar (KG1-62.5AS) diesel generator running at 1500rpm and M.K $12 \mathrm{v}$ battery. Therefore, we recommend taking this system steps further by adding renewable energy sources (wind turbine and photovoltaic). Wind and PV are the primary power source of the system and diesel generator is used as a backup for long-term storage system. On the supplementary hand, the battery is used in the system as a backup for shortterm storage system.

\section{ARCHITECTURE OF THE SYSTEM}

The hybrid energy system architecture designed and simulated in Homer software is shown in figure 1. The projected hybrid renewable energy system involves wind turbine, photovoltaic panel. Diesel generator, battery, and inverter are including as a backup storage system. The system is designed positively for an off grid system for an Institutional area. The homer software is used to realize the greatest optimal sizing and for the system also is used for prefeasibility study of the system. Sensitivity is considered in design the system.

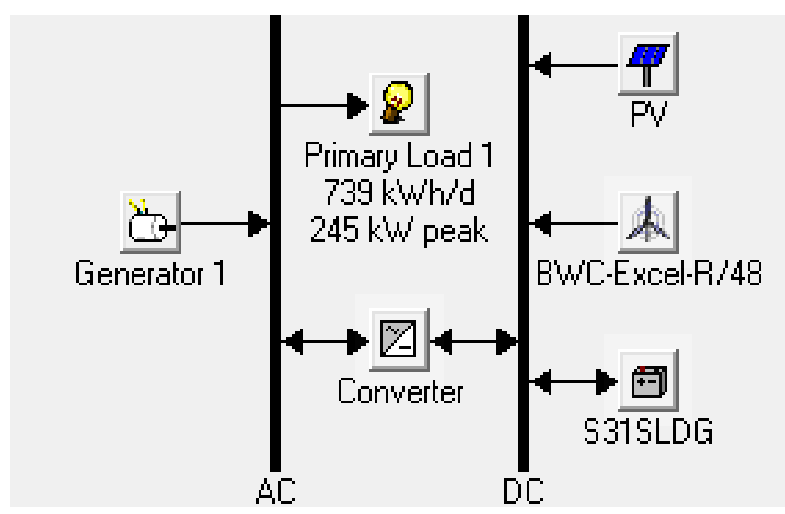

Fig. 1: Solar-wind-diesel stand-alone systems for an Institutional area 


\subsection{Wind Turbine}

BWC-Excel-R/48 is usage in this system. It has rated capacity $7.5 \mathrm{Kw}$ and affords $48 \mathrm{~V}$ DC. Its initial capital cost $\$ 23081$, replacement cost is $\$ 17000$, and yearly operation and maintenance cost is $\$ 462$. The technical factors of wind turbine are shown in Table 1 , which we became from (www.bergey.com). The hub and anemometer is located at 50 meters height. Figure 2 displays the power curve of BWCExcel-R/48 turbine, which expresses the connection between the wind speed and generated power. Wind data for this place still under collection. So, ascending up the wind speed is used to get the estimated wind speed at Institutional site. These data achieved from (http://maps.nrel.gov/swera). Figure 3 shows the wind speed data for Institution with $3.287 \mathrm{~m} / \mathrm{s}$ average wind speed. Three levels of wind speed are excellent for sensitivity analysis.

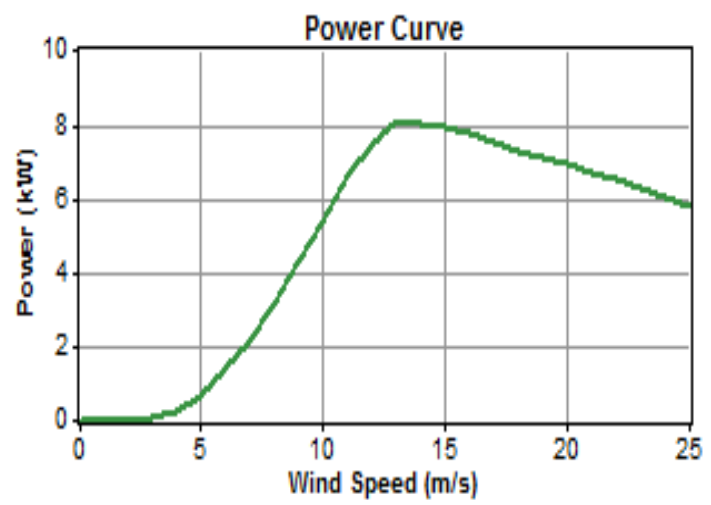

Fig. 2: Wind turbine power curve

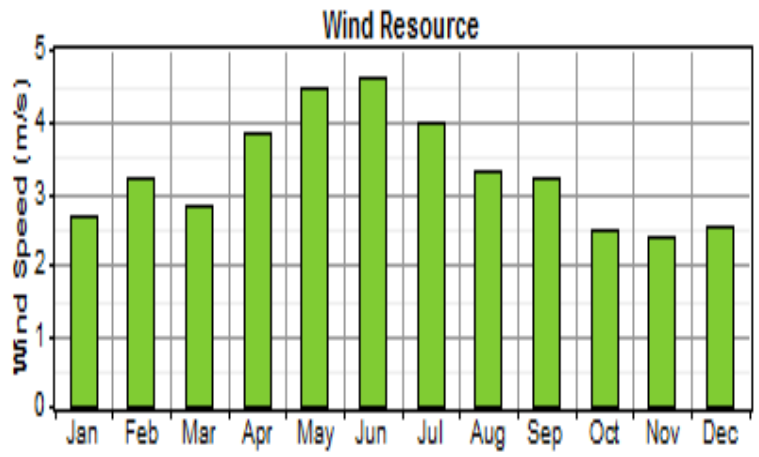

Fig. 3: Average wind speed over a year

Table 1. BWC-Excel-R/48 parameters

\begin{tabular}{|l|c|}
\hline Start-up Wind Speed & $3.4 \mathrm{~m} / \mathrm{s}(7.5 \mathrm{mph})$ \\
\hline Cut-in Wind Speed & $2.5 \mathrm{~m} / \mathrm{s}(5 \mathrm{mph})$ \\
\hline Rated Wind Speed & $12 \mathrm{~m} / \mathrm{s}(27 \mathrm{mph})$ \\
\hline Rated Power & $7.5 \mathrm{Kw}$ \\
\hline Type & 3 Blade Upwind \\
\hline Rotor Diameter & $7 \mathrm{~m}(23 \mathrm{ft})$. \\
\hline Generator & Permanent Magnet Alternator \\
\hline
\end{tabular}

\subsection{Photovoltaic Array}

The second renewable source implemented in this system is ZT300P solar module. There are several different solar panels are available in the streak, but basis on pieces, size, and rating Zytech ZT300P was chosen. The technical factors of wind turbine are presented in Table 2. Because the DC voltage bus is $24 \mathrm{~V}$, two PV sections are connected in series since each element has $12 \mathrm{~V}$. There are $7894 \mathrm{PV}$ panels with every has $38 \mathrm{~W}$. The initial cost of each two panels attach in series is $200 \mathrm{Kw}-\$ 111193$ \& $300 \mathrm{Kw}-\$ 274277$, replacement cost is \$95626 \& \$235878 and operational and maintenance cost is \$1112 \& \$2742. The latitude and longitude of Institute are $26 \mathrm{~N}$ and $75 \mathrm{E}$ separately. The time zone is GMT+5:30 India. The effect of temperature is measured in this system. Figure 4 displays the solar radiation in a year created by HOMER.

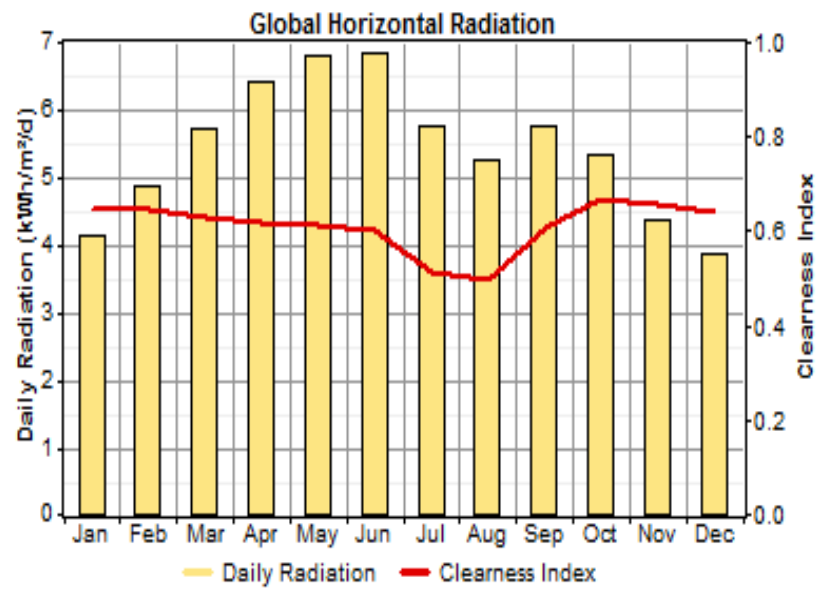

Fig. 4: Monthly solar radiation

\subsection{Diesel Generator}

Kirloskar KG1-62.5AS diesel generator running at 1500rpm is used to deliver $\mathrm{AC}$ power to the system all over the inverter. This generator has capacity of $50 \mathrm{~kW}$. Its initial capital cost is $\$ 6746$, replacement cost is $\$ 5559$, and operational and maintenance cost is $0.050 \$ / \mathrm{hr}$. the almost cost of diesel fuel is $\$ 0.94$ per liter. The manufacture efficiency graph is exposed in figure 5 and fuel consumption data is exposed in table 2 .

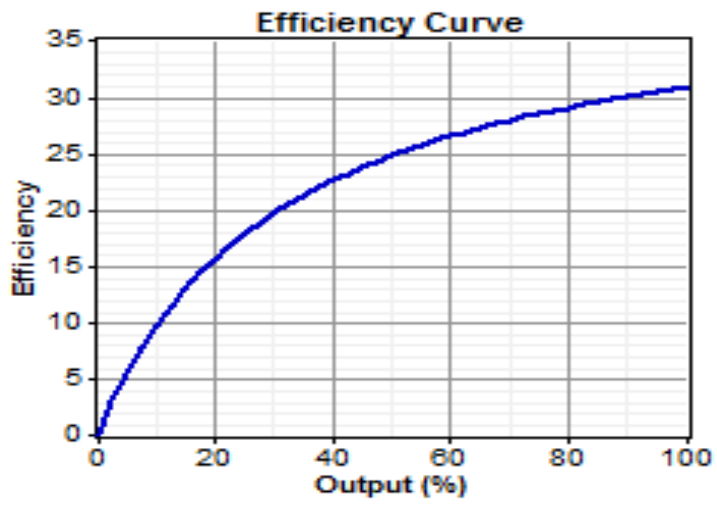

Fig. 5: Efficiency Curve

Table 2. Fuel Consumption Data

\begin{tabular}{|c|c|}
\hline Output Power (Kw) & $\begin{array}{c}\text { Fuel Consumption } \\
\text { (L/hr.) }\end{array}$ \\
\hline 1.000 & 0.250 \\
\hline 10.000 & 2.500 \\
\hline 20.000 & 5.000 \\
\hline 50.000 & 12.500 \\
\hline
\end{tabular}




\subsection{Battery}

Total 200 numbers of batteries of S31SLDG Sealed Gel Cell are used in this system as a backup system and it also continues constant voltage irritated the load. Every battery rate $12 \mathrm{~V}$ and has a capacity $98 \mathrm{Ah}$ with $12 \mathrm{~V}$ total rating. The initial capital cost of all batteries is $\$ 69600$ with replacement cost of $\$ 55600$, and $\mathrm{M} \& \mathrm{O}$ cost is $\$ 6$. The batteries are talented to handle the constant charging and discharging which tells as deep cycle batteries.

\subsection{Converter}

A converter can be an inverter (DC to AC), rectifier (AC to DC), or both. The conventional load is DC type, but generated power from diesel generator is AC type. The average load is $200 \mathrm{~kW}$ and the peak load is $245 \mathrm{~kW}$. The Capital cost of average load is $\$ 71428$ and replacement cost is $\$ 42458$ \& $\mathrm{M} \& \mathrm{O} \$ 714$

\subsection{Demand Load}

The Institutional site day-to-day average AC load is $739 \mathrm{kWh} /$ day. The Institution operates practically the same hourly load during the year. Institution facilities make a small different in the load, especially the air condition. Fig.6 displays a typical load profile for Institutional site produced by HOMER.

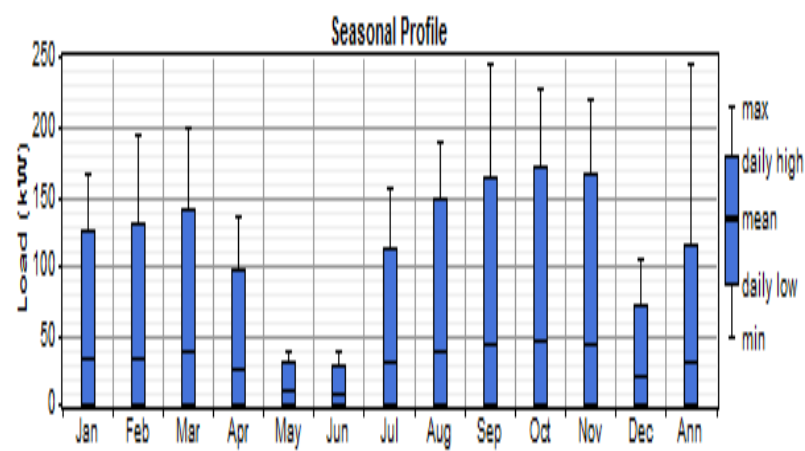

Fig. 6: Load Profile for Institutional area

\section{RESULT AND DISCUSSION}

HOMER allows the user to define different possible sizes of the PV system, Wind System, battery bank, converter and generators. After each simulation, the optimal solution presented by HOMER is the system that, with the sizes and components available, can cover the load within the given technical constraints at minimum cost.

The simulations in HOMER were performed multiple times for each case. For each simulation, multiple evaluations of the results were made shows Fig. 7.

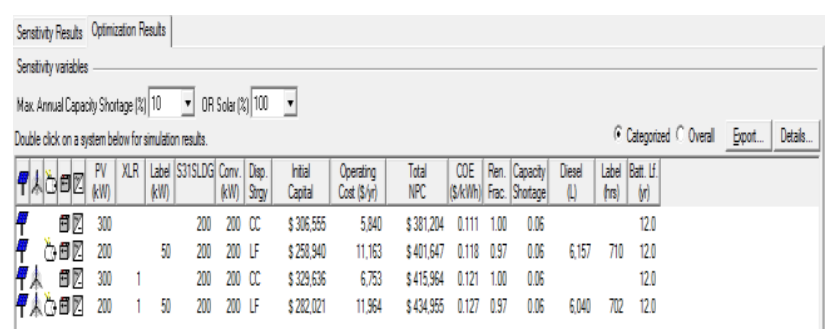

Fig. 7: Optimization results with sensitivity variables

On the basis of cost of energy different combinations were obtained by HOMER.

The first combination obtained by HOMER is Solar with battery and converter, Second combination obtained by
HOMER is Solar-Diesel with battery and converter, Third combination obtained by HOMER is Solar-Wind with battery and converter and Fourth combination obtained by HOMER is Solar-wind-diesel generator with battery and converter.

On the above different combination most Optimal solution obtained by HOMER is Solar with battery and converter for an Institutional area

\subsection{Solar with battery and converter for an Institutional area}

Table 3. System Architecture

\begin{tabular}{|c|c|}
\hline Component & Rating \\
\hline PV & $300 \mathrm{Kw}$ \\
\hline Battery (S31SLDG) & 200 \\
\hline Inverter & $200 \mathrm{~kW}$ \\
\hline Rectifier & $200 \mathrm{~kW}$ \\
\hline Total NPC & $\$ 381,204$ \\
\hline Levelized COE & $\$ 0.111 / \mathrm{kWh}$ \\
\hline Operating Cost & $\$ 5,840 / \mathrm{yr}$. \\
\hline
\end{tabular}

\subsubsection{Cost Summary}

The Cost Summary tab displays cash flows as either a present value or annualized cost, categorized by component or cost type. Three cost outputs, the total net present cost, levelized cost of energy, and the operating cost appear in the top right corner of the Simulation Results window.

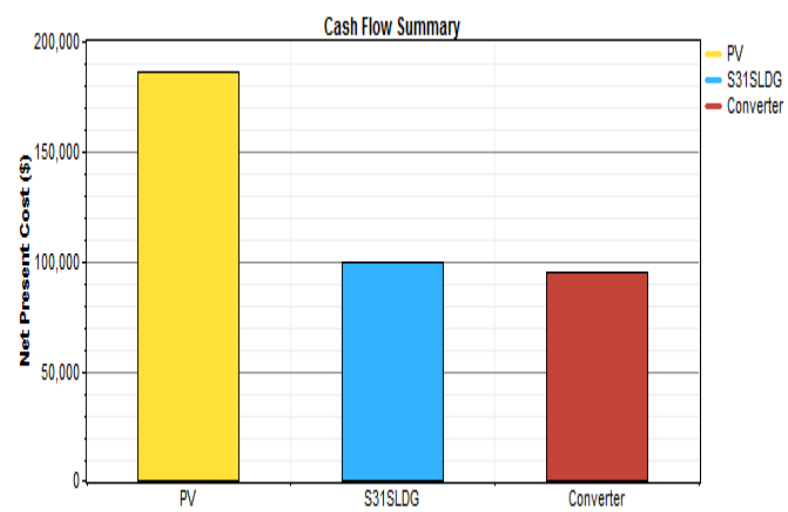

Fig. 8: Net Present Cost V/s different Components

Table 4. Simulation result of Cost Summary

\begin{tabular}{|l|l|l|l|l|}
\hline Component & PV & $\begin{array}{l}\text { Battery } \\
\text { (S31SL } \\
\text { DG) }\end{array}$ & Converter & System \\
\hline Capital (\$) & 165,554 & 69,600 & 71,401 & 306,555 \\
\hline $\begin{array}{l}\text { Replaceme } \\
\text { nt (\$) }\end{array}$ & 0 & 41,364 & 17,887 & 59,250 \\
\hline O\&M (\$) & 21,161 & 77 & 9,366 & 30,603 \\
\hline Fuel (\$) & 0 & 0 & 0 & 0 \\
\hline Salvage(\$) & 0 & $-11,875$ & $-3,329$ & $-15,204$ \\
\hline Total (\$) & 186,715 & 99,165 & $-15,204$ & 381,204 \\
\hline
\end{tabular}




\subsubsection{Cash Flow}

The Cash Flow tab of the simulation results window shows a graph of the system cash flow. Each bar in the graph represents either a total inflow or total outflow of cash for a single year. The first bar, for year zero, shows the capital cost of the system, which also appears in the optimization results. A negative value represents an outflow, or expenditure for fuel, equipment replacements, or operation and maintenance $(\mathrm{O} \& M)$. A positive value represents an inflow, which may be income from electricity sales or the salvage value of equipment at the end of the project lifetime.

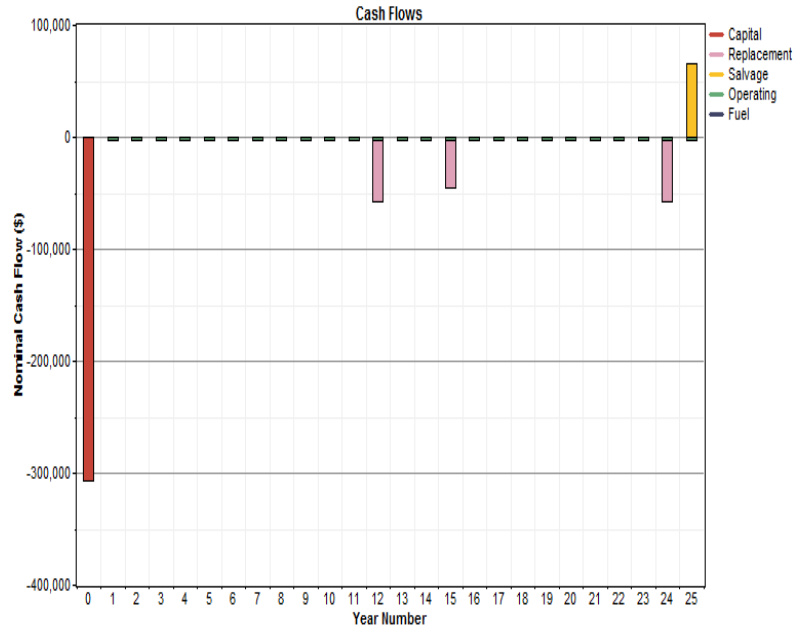

Fig. 9: Nominal Cash Flow V/s Time

\subsubsection{Electrical}

The Electrical tab of the Simulation Results window shows details about the annual production and consumption of electrical energy by the system.

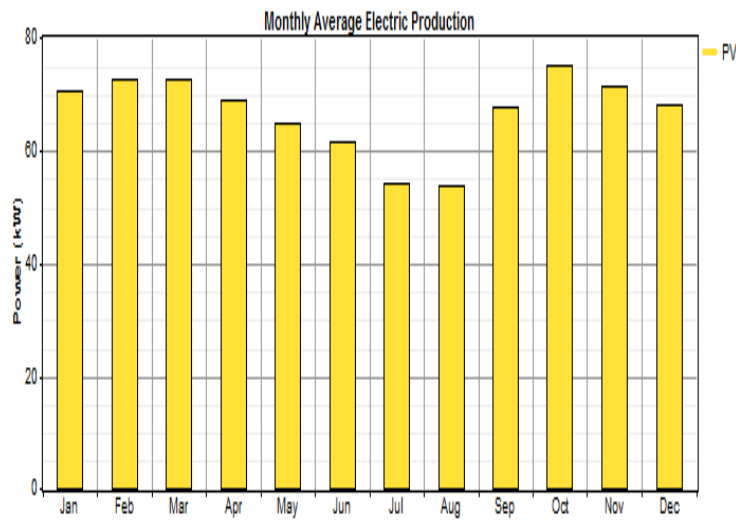

Fig. 10: Power V/s different Time

Table 5. Simulation result of Production (Electrical)

\begin{tabular}{|c|c|c|}
\hline Production & $\mathbf{k W h} / \mathbf{y r}$. & $\mathbf{\%}$ \\
\hline PV array & 584,223 & 100 \\
\hline Total & 5854,223 & 100 \\
\hline
\end{tabular}

Table 6. Simulation result of consumption

\begin{tabular}{|c|c|c|}
\hline Consumption & $\mathbf{k W h} / \mathbf{y r}$. & $\boldsymbol{\%}$ \\
\hline AC primary load & 269,094 & 100 \\
\hline Total & 269,094 & 100 \\
\hline
\end{tabular}

Table 7. Simulation result of Quantity

\begin{tabular}{|l|l|l|}
\hline Quantity & $\mathbf{k W h} / \mathbf{y r}$. & $\mathbf{\%}$ \\
\hline Excess electricity & 276,968 & 47.4 \\
\hline Unmet electric load & 641 & 0.2 \\
\hline Capacity shortage & 16,348 & 6.1 \\
\hline
\end{tabular}

\begin{tabular}{|c|c|}
\hline Quantity & Value \\
\hline Renewable fraction & 1 \\
\hline
\end{tabular}

\subsubsection{PV}

The PV tab shows details about the operation of the PV array if the system contains one. The PV tab of the Simulation Results window contains the following output variables:

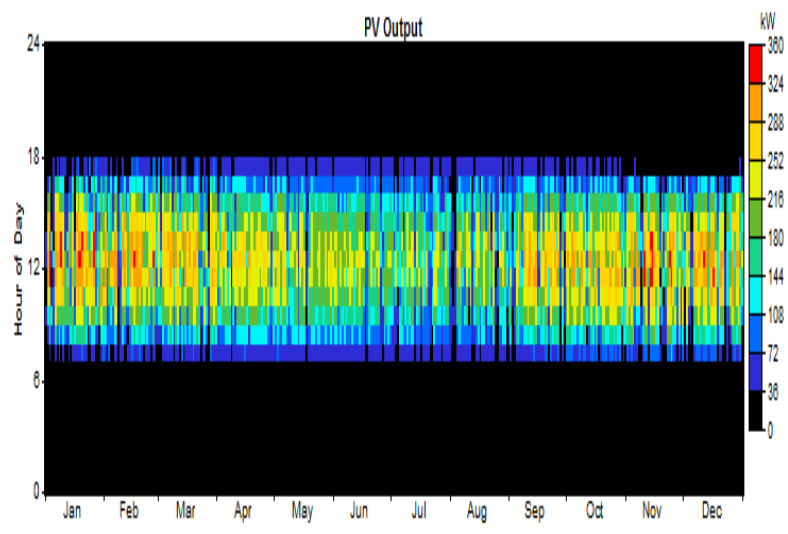

Fig. 11: Hour of Day V/s Months

Table 8. Simulation result of Photovoltaic

\begin{tabular}{|l|c|c|}
\hline Quantity & Value & Unit \\
\hline Rated capacity & 300 & $\mathrm{~kW}$ \\
\hline Mean output & 67 & $\mathrm{~kW}$ \\
\hline Mean output & 1,601 & $\mathrm{kWh} / \mathrm{d}$ \\
\hline Capacity factor & 22.2 & $\%$ \\
\hline Total production & 584,223 & $\mathrm{kWh} / \mathrm{yr}$. \\
\hline Minimum output & 0 & $\mathrm{~kW}$ \\
\hline Maximum output & 352 & $\mathrm{~kW}$ \\
\hline PV penetration & 217 & $\%$ \\
\hline Hours of operation & 4,368 & $\mathrm{hr} / \mathrm{yr}$ \\
\hline Levelized cost & 0.0250 & $\$ / \mathrm{kWh}$ \\
\hline
\end{tabular}

\subsubsection{Battery}

The Battery tab shows details about the use and expected lifetime of the battery. The Battery tab of the Simulation Results window contains the following output variables: 


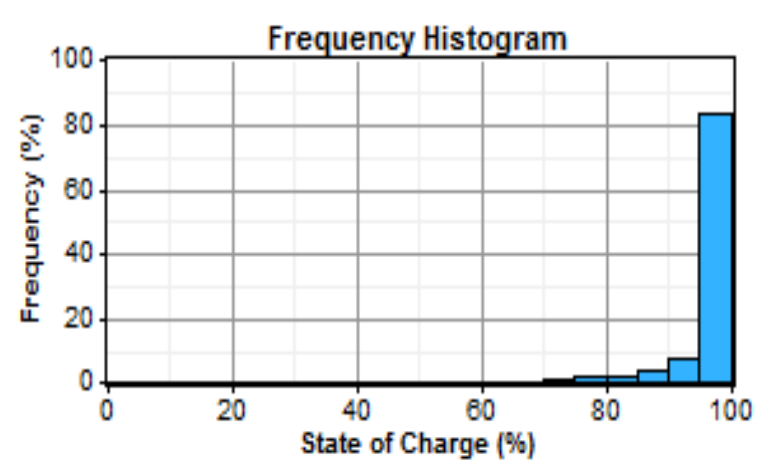

Fig. 12: Frequency V/s State of Charge

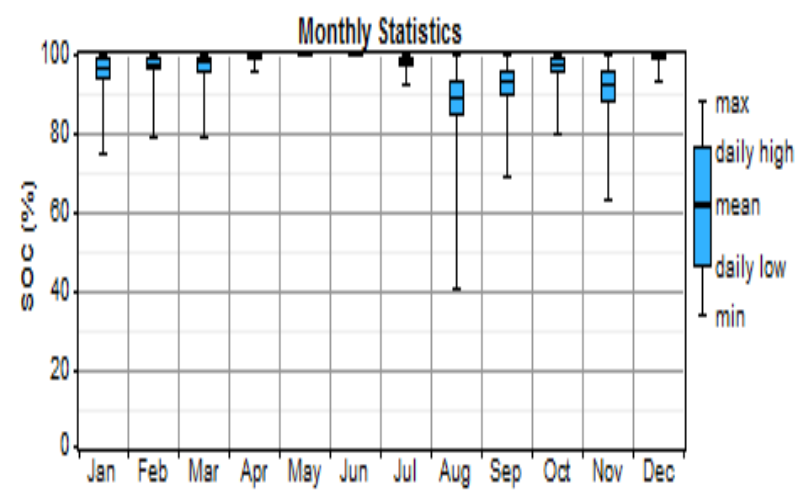

Fig. 13: State of Charge V/s Months

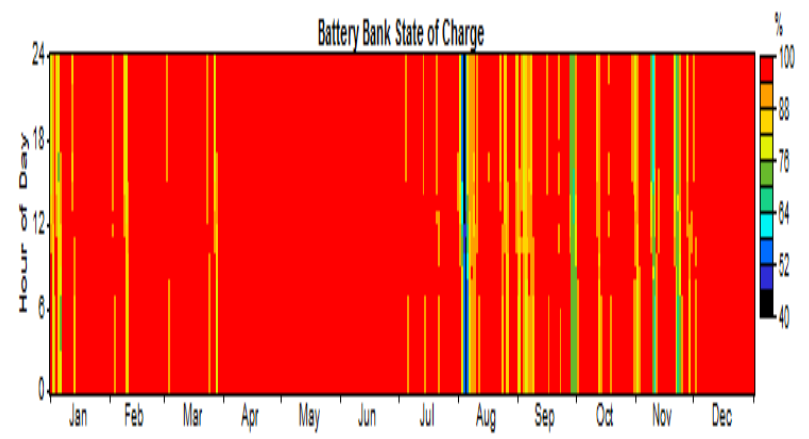

Fig. 14: Hours of Day V/s Months

Table 9. Simulation result of Battery

\begin{tabular}{|c|c|}
\hline Quantity & Value \\
\hline String size & 1 \\
\hline Strings in parallel & 200 \\
\hline Batteries & 200 \\
\hline Bus voltage $(\mathrm{V})$ & 12 \\
\hline
\end{tabular}

\begin{tabular}{|l|c|l|}
\hline Quantity & Value & Unit \\
\hline Nominal capacity & 235 & $\mathrm{kWh}$ \\
\hline Usable nominal capacity & 141 & $\mathrm{kWh}$ \\
\hline Autonomy & 4.58 & $\mathrm{Hr}$. \\
\hline Lifetime throughput & $6,310,598$ & $\mathrm{kWh}$ \\
\hline
\end{tabular}

\begin{tabular}{|l|c|l|}
\hline Battery wear cost & 0.010 & $\$ / \mathrm{kWh}$ \\
\hline Average energy cost & 0.000 & $\$ / \mathrm{kWh}$ \\
\hline Energy in & 41,361 & $\mathrm{kWh} / \mathrm{yr}$. \\
\hline Energy out & 33,098 & $\mathrm{kWh} / \mathrm{yr}$. \\
\hline Storage depletion & 1 & $\mathrm{kWh} / \mathrm{yr}$. \\
\hline Losses & 8,263 & $\mathrm{kWh} / \mathrm{yr}$. \\
\hline Annual throughput & 37,004 & $\mathrm{kWh} / \mathrm{yr}$. \\
\hline Expected life & 12.0 & $\mathrm{Yr}$. \\
\hline
\end{tabular}

\subsection{Converter}

The Converter tab shows details about the operation of the inverter and rectifier, including capacity, electrical input and output, hours of operation, and losses.

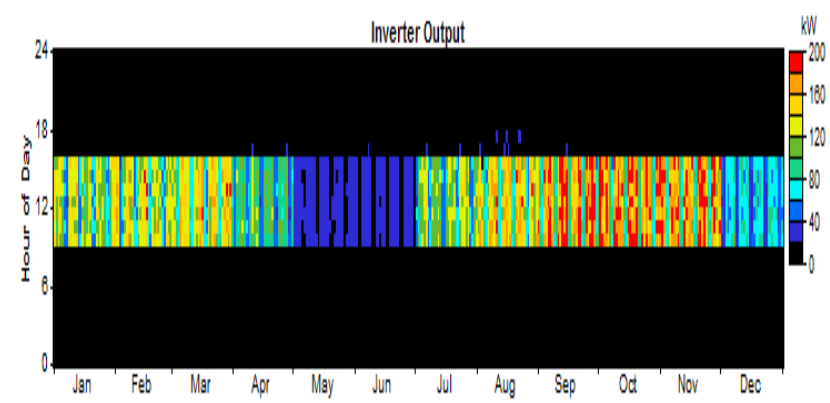

Fig.15: Hour of Day V/s Months

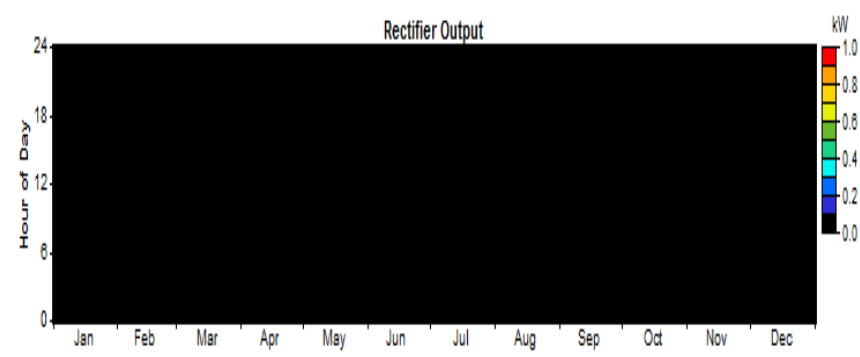

Fig. 16: Hour of Day V/s Months

Table 10. Simulation result of Converter

\begin{tabular}{|l|c|c|l|}
\hline Quantity & Inverter & Rectifier & Units \\
\hline Capacity & 200 & 200 & $\mathrm{~kW}$ \\
\hline Mean output & 31 & 0 & $\mathrm{~kW}$ \\
\hline Minimum output & 0 & 0 & $\mathrm{~kW}$ \\
\hline $\begin{array}{l}\text { Maximum } \\
\text { output }\end{array}$ & 200 & 0 & $\mathrm{~kW}$ \\
\hline Capacity factor & 15.4 & 0.0 & $\%$ \\
\hline $\begin{array}{l}\text { Hours of } \\
\text { operation }\end{array}$ & 8,756 & 0 & $\mathrm{hrs} / \mathrm{yr}$ \\
\hline Energy in & 298,992 & 0 & $\mathrm{kWh} / \mathrm{yr}$. \\
\hline Energy out & 269,094 & 0 & $\mathrm{kWh} / \mathrm{yr}$. \\
\hline Losses & 29,899 & 0 & $\mathrm{kWh} / \mathrm{yr}$. \\
\hline
\end{tabular}




\section{CONCLUSION}

This Paper discusses an overview of solar-wind-diesel standalone System. The major components of SWDSAS including Photovoltaic, wind, diesel generator, Battery, AC-DC power electronics converter, DC-AC power electronics converter are discussed.

The PV shows the meaningful and optimal result among all four combination in terms of Net Present Cost (NPC) and Cost of Energy (COE) generated by simulation model of solar-wind-diesel stand-alone System. NPC and COE of optimal combination is $\$ 381204,0.111 \$ / \mathrm{kWh}$ respectively.

\section{ACKNOWLEDGEMENT}

The authors are thankful to department of Electrical Engineering, Jaipur National University, and Rajasthan, India for making the data available. We are grateful that comments and suggestions provided by anonymous reviewers and editor helped to improve the quality of the paper.

\section{REFERENCES}

[1] Government of Canada Publications, "Status of Remote/Off-Grid Communities in Canada", "Natural Resources Canada," August 2011.

[2] Nabil A. Ahmed, Masafumi Miyatake, 2006 "A standalone hybrid generation system combining solar photovoltaic and wind turbine with simple maximum power point tracking control," IPEMC, IEEE.

[3] K. Agbossou, et al., 2004 "Performance of a stand-alone renewable energy system based on energy storage as hydrogen", IEEE Transactions on Energy Conversion, Vol. 19, No. 3, pp. 633-640, September.

[4] Belfkira, R.; Nichita, C.; Barakat, G, 2008 "Modeling and optimization of wind/PV system for stand-alone site", 18th International Conference on Electrical Machines, 2008. ICEM 2008, pp. 1-6, Sept 6-9.

[5] Lagorse, J; Giurgea, S; Paire, D; Cirrincione, M; Simoes, M.G ; Miraoui, A; 2008 "Optimal Design Analysis of a Stand-Alone Photovoltaic Hybrid System", IEEE Industry Applications Society Annual Meeting, 2008. IAS '08, pp1-7, Oct 5-9.

[6] Hung-Cheng Chen, Jian-Cong Qiu, and Chia-Hao Liu, 2008 "Dynamic modeling and simulation of renewable energy based hybrid power systems", Third International Conference on Electric Utility Deregulation and Restructuring and Power Technologies, 2008. DRPT 2008, pp. 2803-2809, April 6-9.
[7] Razak, N.A.b.A.; bin Othman, M.M.; Musirin, I; 2010 "Optimal sizing and operational strategy of hybrid renewable energy system using homer", 4th International Power Engineering and Optimization Conference (PEOCO), 2010, pp495-501, June 23-24

[8] Karshenas, H. ; Karimi-Ghartemani, M. ; Yazdani, D. Khajehoddin, S.A. ; Zaman, M. ;Bakhshai, A. ; Jani, P; 2010 , "A Hybrid Renewable Energy System for powering Information and Communication Technology (ICT)", 32nd International Telecommunications Energy Conference (INTELEC), pp1-6, June 6-10.

[9] Picklesimer, D. ; Rowley, P. ; Parish, D. ; Carroll, S. Bojja, H. ; Whitley, J.N; , 2010 "Techno-economic optimization of sustainable power for telecommunications facilities using a systems approach", International Symposium on Sustainable Systems and Technology (ISSST), 2010 IEEE, pp1-6, May 17-19.

[10] J.K. Kaldellis, 2010“Optimum hybrid photovoltaic-based solution for remote telecommunication stations", Renewable Energy, Vol, 35, Pages 2307-2315, October.

[11] Juhari Ab. Razak, Kamaruzzaman Sopian, Yusoff Ali, 2007"Optimization of Renewable Energy Hybrid System by Minimizing Excess Capacity", INTERNATIONAL JOURNAL OF ENERGY, Vol. 1

[12] A. S. Neris, et al., 1999 "A variable speed wind energy conversion scheme for connections to weak AC systems", IEEE Transactions on Energy Conversion, Vol. 14, No.1, pp. 122-127, March.

[13] A. M. Knight and G. E. Peters, 2005"Simple wind energy controller for an expanded operating range", IEEE Transactions on Energy Conversion, Vol. 20, No. 2, pp. 459-465, June.

[14] D. Kottick, et al., 1993"Battery energy storage for frequency regulation in an island power system", IEEE Transactions on Energy Conversion, Vol. 8, No. 3, pp. 455-458, September.

[15] A. Sharma, A. Singh, and M. Khemariya, 2013 "Homer Optimization Based Solar PV ; Wind Energy and Diesel Generator Based Hybrid," Int. J. Soft Computer. Eng., vol. 3, no. 1, pp. 199-204.

[16] D. C. Sharma, 2007 "Transforming rural lives through decentralized green power," Futures, vol. 39, no. 5, pp 583-596. 